\title{
Water deficits during reproductive growth of soybeans. II. Water use and water deficiency indicators
}

\author{
JL Dardanelli, EE Suero *, FH Andrade, J Andriani
}

EEA Balcarce, Instituto Nacional de Tecnología Agropecuaria (INTA), Fac de Ciencias Agrarias, Univ Nac de Mar del Plata,
CC 276-7620 Balcarce Bs As, Argentina

(Received 2 November 1990; accepted 11 July 1991)

Summary - An experiment was carried out over 2 years with soybeans to study water use and performance of different indicators of water status under field controlled conditions, comparing an irrigated check with treatments with imposed water deficiencies. Statistically significant differences were found between treatments in predawn water potential (PWP), noon water potential (NWP) and leaf resistance (LR). PWP best reflects soil water availability or percentage of available water (PAW). The determination coefficient $\left(R^{2}\right)$ between PWP:PAW for both years was $0.77^{\star *}$. Water use was reduced when water deficiency was applied, and actual water use: potential evapotranspiration (WU:PET) relationship was drastically reduced for the dry treatments. (0I, 10,00) compared with the control (II), but it recovered almost completely when the deficiency was removed. Total water used efficiency (TWUE), as dry matter: water use (DM:WU) and water use efficiency (WUE); as seed yield: water use (SY:WU), were significantly higher for the second year. A time-integrated deficiency index (DI) was calculated as:

$$
D I=1-\int_{t b}^{t e}(P A W / A W T) \mathrm{d} t,
$$

tb

for all $P A W<A W T$, where to and te are the beginning and the end of the period, and $A W T$ is the PAW threshold $(62 \%)$. Below that value, $W U$ and $D M$ are reduced. Dry matter production and seed yield were related to $D /$ as:

$$
\begin{aligned}
& D M=5.216-1.353 \ln (D I) ; R^{2}=0.75^{\star \star} n=32 \\
& G Y=3.187-0.349 \ln (D I) ; R^{2}=0.61^{\star *} n=32 .
\end{aligned}
$$

Glycine $\max =$ soybean / water use / water stress / water use efficiency / indicator parameter

Résumé - Déficit hydrique durant la phase reproductive du soja. Il. Utilisation de l'eau et indicateurs de déficience en eau. On a effectué durant 2 ans le suivi de l'utilisation de l'eau et de différents indicateurs de l'état hydrique d'une culture de soja dans une expérience en conditions contrôlées en plein champ comportant un contrôle irrigué et 3 traitements d'imposition de sécheresse.

On a constaté des différences significatives entre traitements pour le potentiel hydrique avant l'aurore (PWP), le potentiel hydrique à midi (NWP) et la résistance des feuilles (LR). PWP cependant reflète beaucoup mieux la disponibilité en eau du sol ou le pourcentage d'eau utile (PAW). Le coefficient de détermination ( $\left.{ }^{2}\right)$ (PWP/PAW) a été de $0,77^{\star \star}$ pour les 2 ans.

L'utilisation de l'eau est réduite lors de l'imposition de la sécheresse et la relation entre l'utilisation réelle de l'eau et l'évapotranspiration potentielle (WU:PET) pour les traitements de sécheresse (OI, 10, OO) baisse drastiquement, en comparaison avec le traitement contrôle (II), mais elle se rétablit presque complètement quand le déficit est levé. L'efficience totale d'utilisation de l'eau (TWUE) calculée comme la matière sèche produite divisée par l'eau utilisée (DM WU) et l'efficience d'utilisation de l'eau calculée comme le rendement en grains divisé par l'eau utilisée (SY:WU), ont été significativement plus élevées pour la seconde année.

On a calculé un indice de déficit intégré dans le temps à partir de la formule:

$$
\mathrm{DI}=1-\int_{\mathrm{tb}}^{\mathrm{te}}(\mathrm{PAW} / \mathrm{AWT}) d \mathrm{t} \text {, }
$$

\footnotetext{
* Correspondence and reprints
} 
pour toutes les situations PAW< SWT où tb et te sont l'initiation et la fin de la période considérée, et AWT est le seuil de $\mathrm{PAW}=62 \%$. En-dessous de ce seuil, WU et DM sont réduits. La production de matière sèche et le rendement sont en relation avec $\mathrm{DI}$ selon les relations suivantes :

$$
\begin{aligned}
& \mathrm{DM}=5,216-1,353 \ln (\mathrm{DI}) ; \mathrm{R}^{2}=0,74^{\star \star} \mathrm{n}=32 \\
& \mathrm{SY}=3,187-0,349 \ln (\mathrm{DI}) ; \mathrm{R}^{2}=0,61^{\star *} \mathrm{n}=32
\end{aligned}
$$

Glycine max = soja / consommation d'eau / déficience en eau / efficience d'utilisation de l'eau / paramètre indicateur

\section{INTRODUCTION}

The effect of drought during different subperiods in soybean crops has been established under controlled conditions (Mingeau, 1974; Sionit and Kramer, 1977), and also in field experiments with plastic covers to exclude rainfall (Doss et al, 1974; Brown et al, 1985), and without protection (Ashley and Ethridge, 1978; Korte et al, 1983; Kadhem et al, 1985; Puech and Bouniols, 1986).

In Balcarce, the $R_{1}-R_{7}$ period occurs during January and February, when the mean difference between potential evapotranspiration and rainfall is $167 \mathrm{~mm}$ (50-year record), which must be supplied by the soil water. Then the possibility that a crop uses as much water as needed depends on the soil water at the depth at which the roots are actively growing. A more intense soil exploration can be expected under conditions of water deficiency (Maertens, 1986), but no agreement exists on the soil depth explored by soybean roots. Mayaki et al (1976), Kaspar et al, (1978, 1984); Willat and Taylor (1978); Reicosky and Deaton (1979); Hoogenboom et al (1987), found soybean roots at 1-2 $\mathrm{m}$, and Maertens (1986) at 2-3 meters; but Cox and Jolliff (1987) reported little soil water absortion below $90 \mathrm{~cm}$.

Total dry matter production for several crops is linearly related to water use (Hanks, 1983). Mingeau (1974), Puech et al (1978) and Scott et al (1987) verified the relation for soybean under different environmental conditions.

Correlations between seed yield and water use may be improved by measuring the effect of deficiencies during critical growth stages (Kanemasu, 1983) since the part of the plant most affected is that which actively grows at the time the deficiency occurs (Donald and Hanblin, 1976).

Several indicators of plant water status have been recommended by Begg and Turner (1976), Kramer (1983), and Cox and Jolliff (1987). Predawn water potential (PWP) and leaf resistance $(L R)$ have been suggested by Hiler and Howell
(1983). Cox and Jolliff (1987) used leaf temperature (LT) measured with a porometer to compare soybean under well watered and dry treatments. Plant and soil deficiency indicators were used by Hiler (1973) to develop a stress day index.

Changes in deficiency indicators must be associated with changes in physiological processes responsible for crop yields. One of the processes most affected by water stress is transpiration. It has been demonstrated for several crops (Ritchie et al, 1972; Shouse et al, 1982) that when percentage of available water (PAW) is above a given value, transpiration depends on the climatic demand, and below this value the ratio actual: maximum evapotranspiration drops dramatically. In cowpea actual transpiration: maximum transpiration also showed a clear response to a threshold value of predrawn water potential (Shouse et al, 1982). Reduction in soybean transpiration and photosynthesis has been reported in response to a similar water deficiency (Boyer, 1970; Huang et al, 1975). A reduction in dry matter can be expected as a consequence of lower transpiration.

The objective of this study was to examine the performance of some indicators and their threshold values, and to study how water deficiencies that normally occur in the area during soybean reproductive period modify soil water extraction pattern and affect both water consumption and production and their relationship.

\section{MATERIALS AND METHODS}

The experiment was a complete randomized block design, with 4 treatments: a control (II), kept over 50 percentage available water (PAW), and $3 \mathrm{dry}$ treatments imposed during the following periods (adapted from Fehr and Caviness, 1977): $R_{1}-R_{4}$ (0l); $R_{4}-R_{6.3}(10)$ and both $R_{1}-R_{4}$ and $R_{4}-R_{6.3}(00)$.

Daily climatic values were obtained from the meteorological station located $1000 \mathrm{~m}$ from the experimental site. In table I some averaged data have been presented. Rainfall was measured with a rain gauge in 
Table I. Soil properties: typic argiudol, Balcarce, Bs As, Argentina.

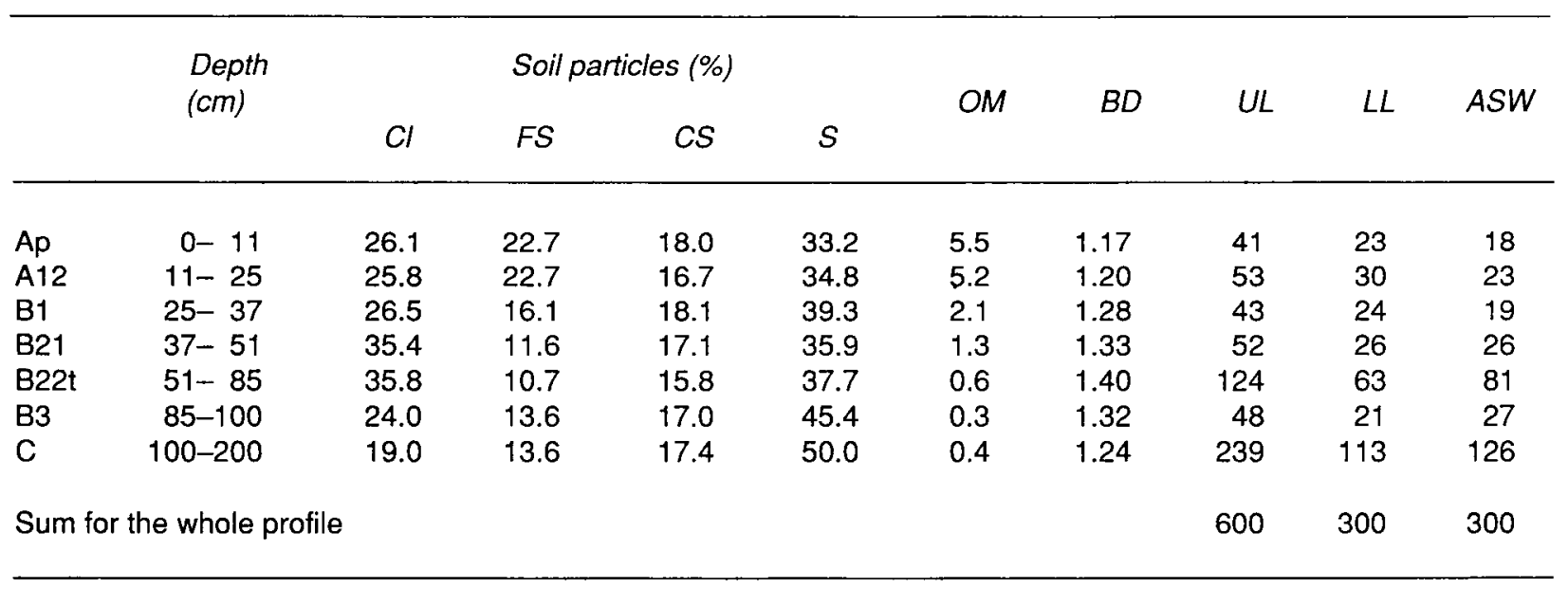

Cl: Clay, 0-2 microns; FS : fine silt, 2-6 microns; CS: coarse silt, 6-200 microns; S: sand, 200-2 000 microns; OM: organic matter, $\%$; BD: bulk density, Mg.m-3; UL and LL: upper and lower limit of soil water, $\mathrm{mm}$; ASW: available soil water, $\mathrm{mm}$.

the center of the experimental site and irrigation applied with 5 rain gauges per plot.

The soil was a Typic Argiudol (fine, illitic clay, thermic), $2 \mathrm{~m}$ in depth. Table II presents some of the soil characteristics. Details of the field experiment have been described by Andriani et al (1991).

Soil water content was measured weekly using a neutron probe (Troxler $103 \mathrm{~A}$ and 2651). Access tubes were installed to a depth of $2 \mathrm{~m}$ (1 per plot in 1986 and 2 in 1987). The probe was calibrated with volumetric soil samples.

Total available water (TAW) for the entire profile is the sum of the available water (AW) on each soil layer, and:

$$
A W(\mathrm{~mm})=U L-L L
$$

The upper limit $(U L)$ in $\mathrm{mm}$, is the constant soil water content in each soil layer after drainage of the excess applied water under non evaporative conditions. The lower limit $(L L)$ was estimated as:

$$
L L(\mathrm{~mm})=U L \times A / B
$$

$A$ and $B$ being the amount of water $(\mathrm{mm})$ in disturbed soil samples at -1.5 and $-0.033 \mathrm{MPa}$, respectively.

The maximum water holding capacity for the modal soil profile was $600 \mathrm{~mm}$ and the TAW $300 \mathrm{~mm}$.

The percentage of available water (PAW) at a given time and at the root depth ( $z$ layers), was calculated as:

$$
P A W=100 \sum_{i=1}^{z}[(S W C-L L) / A W]
$$

\begin{tabular}{|c|c|c|c|c|c|c|c|c|c|c|c|c|}
\hline \multicolumn{2}{|c|}{$\begin{array}{c}\text { Solar } \\
\text { radiation }\end{array}$} & \multicolumn{2}{|c|}{$\begin{array}{l}\text { Mean max } \\
\text { temp }\end{array}$} & \multicolumn{2}{|c|}{$\begin{array}{l}\text { Mean } \\
\text { VPD }\end{array}$} & \multicolumn{2}{|c|}{ PET } & \multicolumn{2}{|c|}{$\begin{array}{c}\text { Mean } \\
R H\end{array}$} & \multicolumn{2}{|c|}{ Rainfall } & \multirow[t]{2}{*}{ ST } \\
\hline 1986 & 1987 & 1986 & 1987 & 1986 & 1987 & 1986 & 1987 & 1986 & 1987 & 1986 & 1987 & \\
\hline 24.0 & 24.2 & 23.4 & 23.2 & 9.8 & 10.6 & 5.7 & 5.6 & 60 & 56 & 193 & 61 & 1 \\
\hline 24.1 & 22.0 & 25.1 & 23.3 & 10.7 & 7.9 & 5.8 & 4.9 & 61 & 57 & 7 & 116 & II \\
\hline 25.5 & 26.1 & 27.8 & 27.6 & 17.0 & 18.5 & 6.5 & 6.7 & 65 & 67 & 56 & 100 & III \\
\hline 25.1 & 21.7 & 29.4 & 24.3 & 19.7 & 10.5 & 6.0 & 4.8 & 72 & 59 & 42 & 63 & IV \\
\hline 13.7 & 15.0 & 24.5 & 24.6 & 10.6 & 8.7 & 3.4 & 3.3 & 40 & 46 & 108 & 22 & V \\
\hline
\end{tabular}

Table II. Meteorological parameters during soybean growing season in 1986/1987 and 1987/1988, Balcarce, Bs As, Argentina.

Solar radiation, MJ.m-2.day-1; mean maximum temperature, ${ }^{\circ} \mathrm{C}$; vapour pressure deficit (VPD), mb; potential evapotranspiration (PET), mm.day-1; Doorenbos and Pruitt, 1977; mean relative humidity $(R H)$, \%; rainfall, mm; stages (ST): I: $S-V_{3} ; I I: V_{3}-R_{1} ; I I I: R_{3}-$ $R_{1} ; I V: R_{4}-R_{6.3} ; V: R_{6}-R_{8}$. Fehr and Caviness, 1977. 
where SWC is the soil water content at the time of measurement.

The crop actual water use (WU), was calculated with a hydrological balance:

$$
W U(\mathrm{~mm})=1+R-S V
$$

where 1 : irrigation $(\mathrm{mm}) ; R$ : rainfall $(\mathrm{mm})$; and $S W$ : variation in soil water storage $(\mathrm{mm})$, between 2 dates for all SWC lower than UL.

Leaf water potential was measured with a Scholander type chamber between 5.00 and 7.00 am for predawn water potential (PWP) and between 12.00 and $3.00 \mathrm{pm}$ for noon water potential (NWP). Leaf resistance $(L R)$ and leaf temperature $(L T)$ were measured with a steady state gas diffusion porometer (Licor 1600 ) of both faces of 3-5 leaves.

ANOVA and Duncan's tests were applied to find differences between treatments and for means comparisons respectively, at the $5 \%$ significance level. The least-squares method was used to find the best fit for the water stress indicators.

A PAW value that produced clear changes in $P W P$ and in the water use: maximum evapotranspiration (WU:MET) ratio was identified using the analysis proposed by Cate and Nelson $(1965,1971)$ to separate 2 populations with different responses to a given factor.

The deficiency index $(D I)$ was calculated as the time integral from to (beginning time), to te (ending time) of the period with PAW below the available water threshold $(A W T)$ :

$$
D I=1-\int_{t b}^{t \theta}(P A W / A W T) \cdot \mathrm{d} t
$$

for all PAW lower than AWT.

\section{RESULTS AND DISCUSSION}

\section{Water deficiency indicators}

The evolution of water deficiency indicators is shown in figure 1. Percentage available water
(PAW); predawn water potential (PWP), and noon water potential (NWP) in the leaves and leaf resistance $(L R)$ showed significant differences $(P<0.05)$ between the dry treatments $(01,10$, $00)$ and the control (II). Significant differences were found between dry and wet treatments in LR (Heatherly et al, 1977; Neyshaboury and Hatfield, 1986; Cox and Jolliff, 1987; in NWP (Brady et al, 1974; Heatherly et al, 1977; Mason et al, 1982; Cortes and Sinclair, 1986; Neyshaboury and Hatfield, 1986; Cow and Jolliff, 1987), and in PWP (Brady et al, 1974; Heatherly et al, 1977; Turner et al, 1978; Cortes and Sinclair, 1986).

PAW was chosen as a standard to test the plant indicators, because it is unaffected by daily climatic changes. As no incidence of plant age was found (Sionit and Kramer, 1976; Turner et al, 1978), both early and late deficiency data were included in the relations presented in table III. Poor association between $P A W$ and $L R$ was found even though the $L R$ values for the dry treatments were always higher than those reported by Neyshaboury and Hatfield (1986) as critical for indeterminate soybean net photosynthesis (250 s.m ${ }^{-1}$ ).

Leaf temperature $(L T)$ was a clear sign of water stress only with high climatic demand (air temperature $>30{ }^{\circ} \mathrm{C}$ ) and low PAW (<30\%). This agrees with the findings of Cox and Jolliff (1987).

Great dispersion in NWP was found at high $P A W$. During the first year, when PAW was lower, a better NWP:PAW relationship was obtained. Heatherly et al (1977) found that NWP was less affected by climatic demand when the soil was dry. Brady et al (1974) reported that PWP was better related to soil water potential than NWP because it was less affected by climate. NWP during the dry periods was always $<-1.1 \mathrm{MPa}$ (fig 1). Soybean net photosynthesis has been reported as affected by NWP ranging

Table III. Relationship between percentage available water (PAW) and predawn leaf water potential (PWP), noon leaf water potential (NWP) and leaf resistance $(L R)$ for the 2 years of soybean experiments.

$\begin{array}{lllllll}\text { PAW:PWP } & 0.69^{\star \star} & (n=160) & p=1 & 0.81^{\star \star} & (n=96) & p=2 \\ \text { PAW: NWP } & 0.51^{\star \star} & (n=160) & p=1 & 0.42^{\star \star} & (n=96) & p=2 \\ \text { PAW : LR } & 0.25^{\star \star} & (n=140) & p=3 & 0.45^{\star \star} & (n=96) & p=6\end{array}$



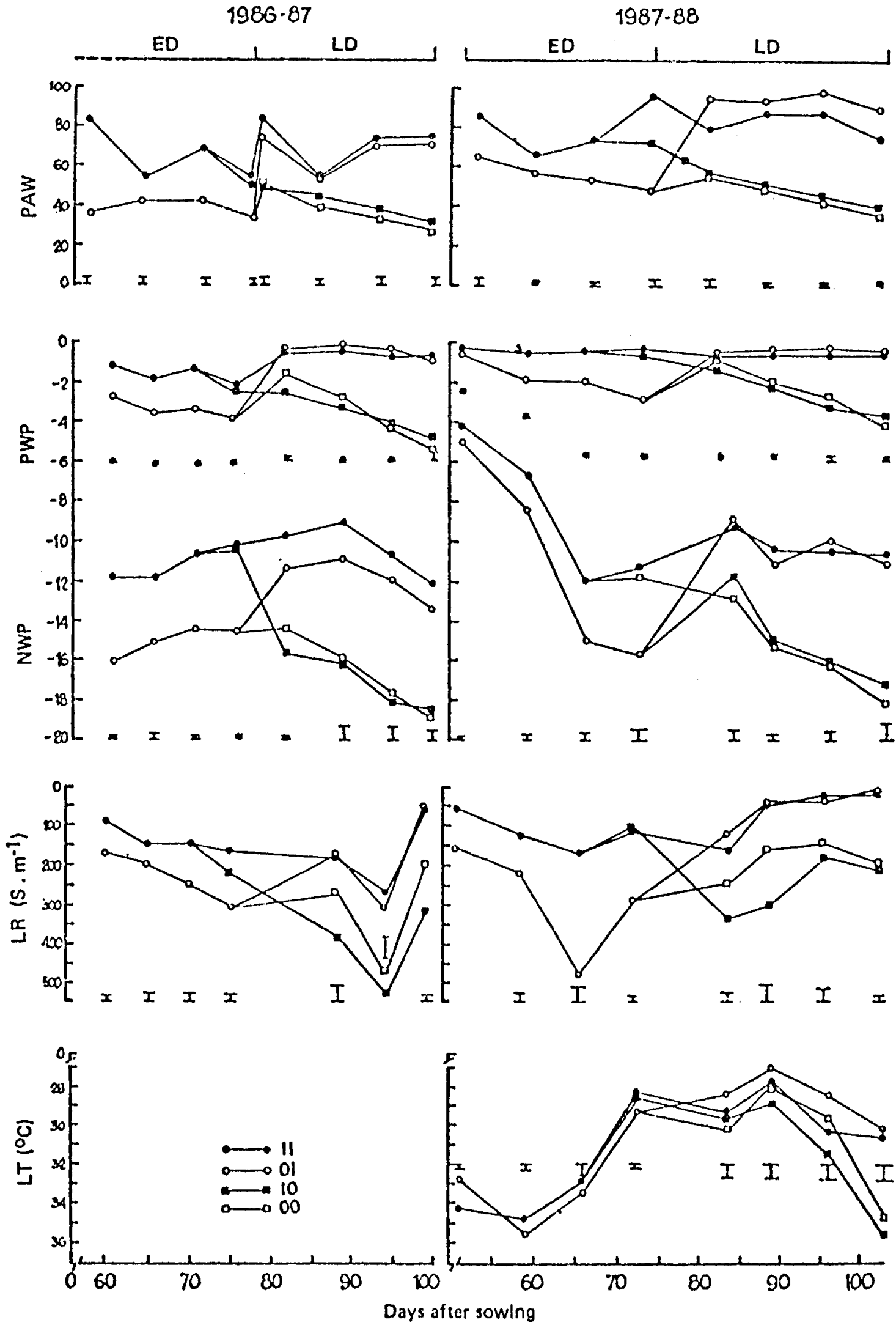

Fig 1. Percentage of available water, predawn water potential and noon water potential in the leaves (in MPa), leaf resistance and leaf temperature. $E D$ and $L D$ refer to early and late deficiencies. Vertical lines represent standard deviations, * indicating values smaller than the symbol used. 
from -1.2 MPa (Boyer, 1970; Cox and Jolliff, 1986; Neyshabouri and Hatfield, 1986) to -1.5 MPa (Turner et al, 1978). NWP seems to be a good indicator of crop water deficiencies only under similar climatic demands.

The relations between all the parameters with PAW were in general better the second year (table III) because of a larger number of subsamples (doubled in 1987/1988). An exponential equation gave the best fit for the relationship between PWP and PAW $\left(R^{2}=0.77^{\star *} ; n=256\right)$. Brady et al (1974) reported similar $R^{2}$ for the relationship PWP: soil water potential.

The ratio actual water use to maximum crop evapotranspiration (WU:MET) was related to PAW (fig 2b). Paired $W U$ and MET data were selected to fulfill the requirements of $M E T$ for the control treatment (high PAW and 95\% photosynthetic active radiation intercepted for dry treatments (to reduce the incidence of soil evaporation). Below a critical PAW of 62 the crop evapotranspiration was reduced (WU:MET = 0.75). Brun et al (1985) suggested that with $P A W=50$ the soybean water use was $74 \%$ of the MET. Burch et al (1978) found that PAW = 50 was a threshold for the ratio WU:MET, and Constable and Hearn (1980), reported that for maximum yield, $P A W>60$ was required during pod filling.

Below the critical PAW threshold of $62 \%$ PAW affected WU. This threshold was related to $P W P$ $=-0.14 \mathrm{MPa}$, using the method suggested by Cate and Nelson $(1965,1971)$ as shown in figure 2a. Consequently, $P W P=-0.14 \mathrm{MPa}$ can also be used as a threshold value associated with reduced water use.

\section{CROP WATER USE}

Figure 3a shows cumulative water use for the different treatments. The dry treatments $(10,0 \mathrm{l}$, $00)$ used less water in the second year because of the lower climatic demand (see table il). In both years, $W U$ was reduced compared with the control immediately after starting the early and late deficiency periods $(E D, L D)$, recovering upon re-irrigation.

Figure $3 \mathrm{~b}$ shows the time evolution of the ratio between water use (WU) and Penman potential evapotranspiration (PET) as calculated by Doorenbos and Pruitt (1977). The water used for the control (II) is considered the maximum crop evapotranspiration (MET) and the ratio $M E T: P E T$ the crop coefficient $\left(K_{\mathrm{c}}\right) . K_{\mathrm{c}}$ values $>$
1.0 were obtained after $95 \%$ of $P A R$ was intercepted, and the maximum value $\left(K_{\mathrm{c}}=1.6\right)$ was achieved at the $R_{6}-R_{7}$ stage.

\section{SOIL WATER EXTRACTION PATTERNS}

Figure 4 shows that the depth of water extraction was strongly modified by the drought treatments. At the end of the early deficiency $\left(R_{4}\right.$ stage), treatments $0 \mathrm{l}$ and 00 explored at least at $180 \mathrm{~cm}$ of soil profile compared with $140 \mathrm{~cm}$ of treatments 10, II. The maximum soil depth $(190 \mathrm{~cm})$ was explored at 85 days in treatments $0 \mathrm{I}, 00$ and at 115-120 days in treatments II and 10 .
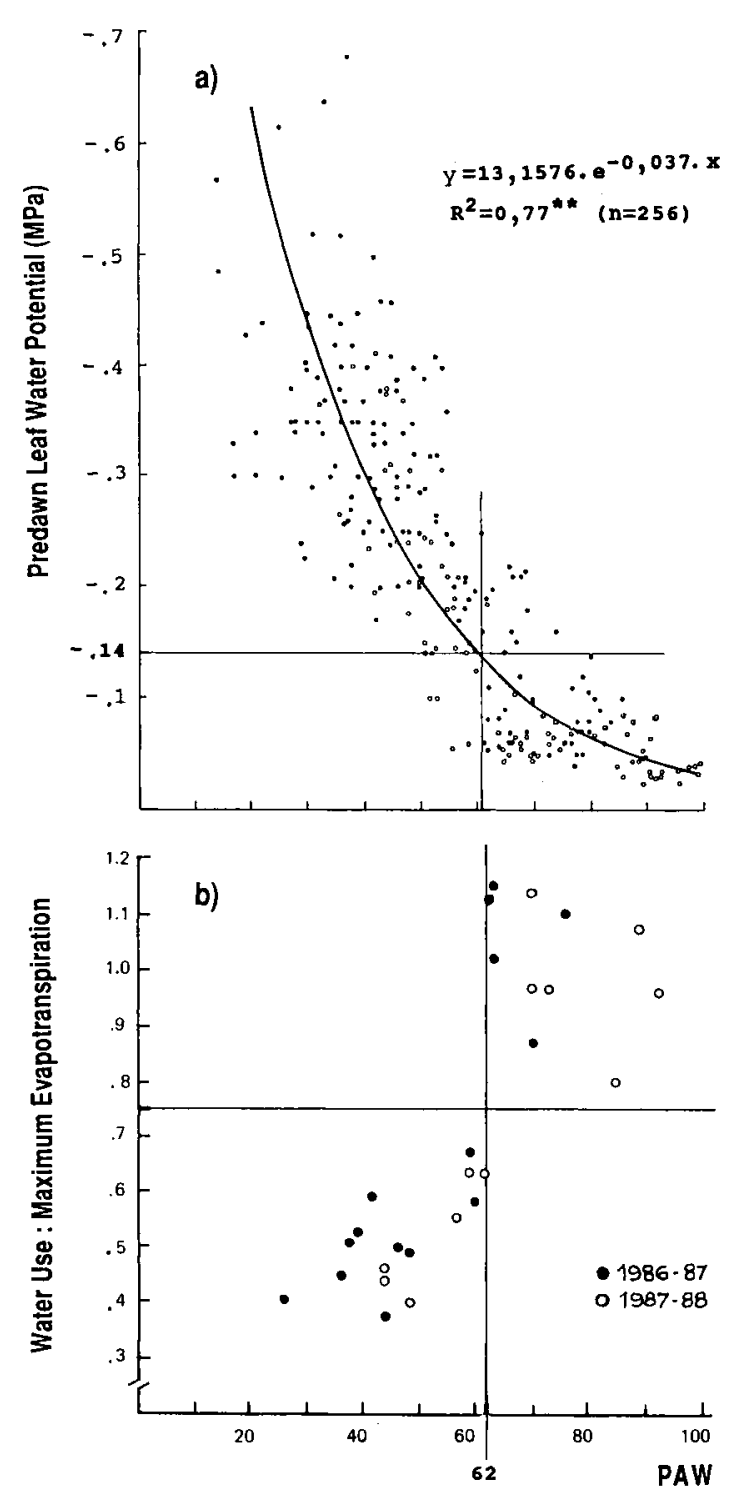

Fig 2. a) Relationship between predawn leaf water potential (in $\mathrm{MPa}$ ), and percentage of available water. b) Relationship between water use in the treatment 10 : maximum evapotranspiration, and percentage of available water. 

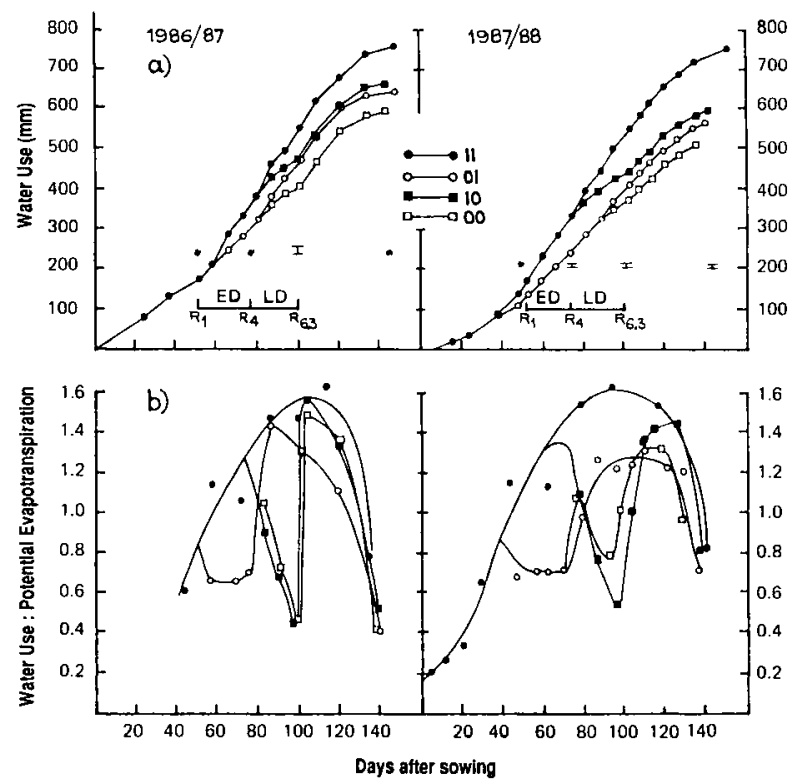

Fig 3. a) Soybean cumulative water use during 2 growing seasons (1986/1987 and 1987/1988). ED and $L D$ refer to early and late deficiencies. b) Water use: potential evapotranspiration relationships for soybean crop.

Upon re-irrigation, water extraction patterns became similar for all treatments. These observations are in agreement with Mason et al (1982), who found soybean water extraction during dry periods down to $260 \mathrm{~cm}$. When the upper $70 \mathrm{~cm}$ of the soil was rewetted no water extraction occured below $90 \mathrm{~cm}$.

Deep root water absorption patterns observed in this study are similar to those reported by Willat and Taylor (1978) and Mason et al (1982), but Cox and Jolliff (1987) under very intense and continuous drought reported only a low water extraction below $90 \mathrm{~cm}$.

\section{WATER USE EFFICIENCY}

Above ground dry matter (DM), seed yield (SY), water use $(W U)$, total water use efficiency as DM:WU (TWUE) and water use efficiency as $S Y: W U$ (WUE) are presented in table IV. High influence of the soil evaporation on $W U$ can be expected from sowing to $V_{3}$ period because of the scarce crop cover. Total rainfall and its frequency favored evaporation the first year producing a WU $50 \mathrm{~mm}$ higher than in the second year.

Differences in DM accumulation from $\mathrm{R}_{1}$ were associated with water deficiency indicators (Andriani et al, 1991). PAW and PWP were more favorable in the second year (fig 1), giving higher TWE values the second year (table IV).

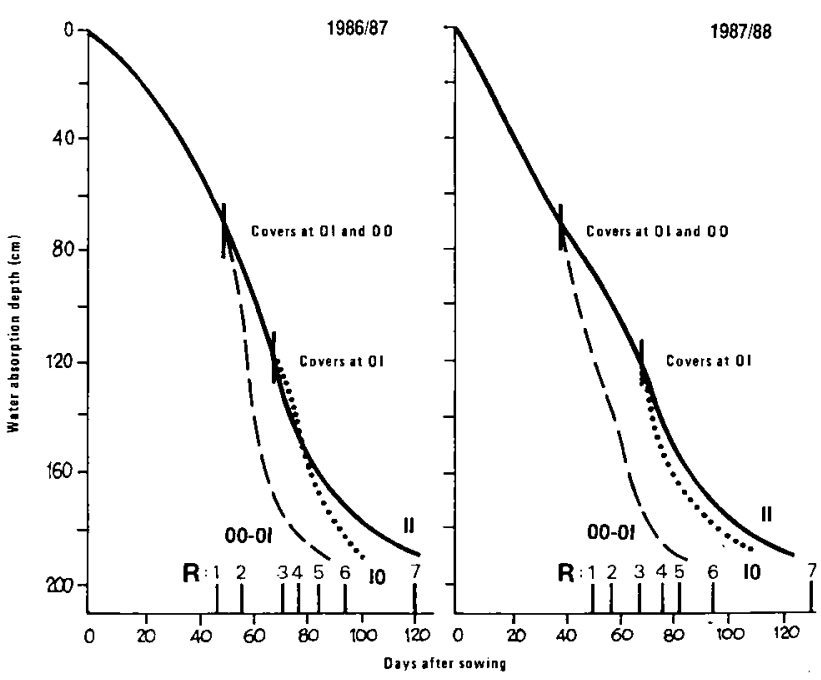

Fig 4. Water absorption depth evolution under soybean crop during 2 growing seasons (1986/1987 and 1987/1988), for different deficiency treatments $(00,01,10,11)$.

The quantitative relationship between $D M$ and $W U$ is strongly affected by environmental conditions ie, the water saturation deficit in the air. With low relative humidity and high temperature, the WUE is reduced. High values of water saturation deficit occurred during the late deficiency (LD) period the first year (table II), reducing TWUE. The WU adjusted by vapour pressure deficit gives a better relation with $D M$ accumulation (Van Keulen and Van Laar, 1986).

Water deficiency during $R_{1}-R_{4}$ period reduced $D M$ production without affecting $S Y$; consequently, WUE was in general higher for the treatments 01 and 00 (table IV). Snyder et al (1982) found higher WUE when water shortage was imposed on an indeterminate soybean crop during $\mathrm{R}_{2}-\mathrm{R}_{4}$.

The linear relationship between WU:MET and seed yield proposed by Merrien (1987) for indeterminate soybean cultivars is only applicable in our experiment to the treatments with equal WUE.

\section{DEFICIENCY INDEX}

Since $P A W=62$ has proved to give a good indication of water deficiencies during the reproductive period, this value was used as a threshold to calculate a deficiency index for each drought treatment.

DI during $R_{1}-R_{8}$ was related to dry matter (DM) and since no effect of water deficiency during flowering on seed production has been 
Table IV. Soybean crop during 1986/1987 and 1987/1988. Total dry matter (DM), seed yield at 13\% humidity (SY), water use (WU), total water use efficiency (TWUE), as $D M: D U$, and water use efficiency (WUE), as $S Y: W U$.

\begin{tabular}{|c|c|c|c|c|c|c|}
\hline Year & Treat & $\begin{array}{c}D M \\
\left(k g . h a^{-1}\right)\end{array}$ & $\begin{array}{c}S Y \\
\left(k g \cdot h a^{-1}\right)\end{array}$ & $\begin{array}{l}W U \\
(m m)\end{array}$ & $\begin{array}{c}T W U E \\
\left(\mathrm{~kg} \cdot m m^{-1}\right)\end{array}$ & $\begin{array}{c}\text { WUE } \\
\left(\mathrm{kg} \cdot \mathrm{mm} \mathrm{m}^{-1}\right)\end{array}$ \\
\hline \multirow[t]{2}{*}{$1986 / 1987$} & $\begin{array}{l}11 \\
01 \\
10 \\
00\end{array}$ & $\begin{array}{r}11150 a \\
8100 b \\
7897 b \\
6862 c\end{array}$ & $\begin{array}{l}4560 a \\
4431 a \\
3783 b \\
3569 b\end{array}$ & $\begin{array}{l}751 a \\
649 b \\
665 b \\
593 c\end{array}$ & $\begin{array}{l}14.8 a \\
12.5 b \\
11.9 b \\
11.6 b\end{array}$ & $\begin{array}{l}6.1 \mathrm{~b} \\
6.8 \mathrm{a} \\
5.7 \mathrm{~b} \\
6.0 \mathrm{~b}\end{array}$ \\
\hline & $S D$ & 152 & 140 & 8 & 0.3 & 0.2 \\
\hline \multirow[t]{2}{*}{$1987 / 1988$} & $\begin{array}{l}11 \\
01 \\
10 \\
00\end{array}$ & $\begin{array}{c}12496 \mathrm{a} \\
9589 \mathrm{bc} \\
9923 \mathrm{~b} \\
8464 \mathrm{c}\end{array}$ & $\begin{array}{l}5 \text { 507a } \\
4891 a b \\
4422 b \\
4437 b\end{array}$ & $\begin{array}{l}753 a \\
566 b \\
600 b \\
510 c\end{array}$ & $\begin{array}{l}16.6 a \\
16.9 a \\
16.5 a \\
16.6 a\end{array}$ & $\begin{array}{l}7.3 b \\
8.6 a \\
7.4 b \\
8.7 a\end{array}$ \\
\hline & SD & 332 & 191 & 11 & 0.4 & 0.2 \\
\hline
\end{tabular}

found, only the $D /$ during $R_{4}-R_{8}$ was related to seed field (SY) (fig 5). Better response was obtained for the relationship DM:DI $\left(R^{2}=0.74^{* *} n=\right.$ 32) than for $S Y: D I\left(R^{2}=0.61^{\star \star} n=32\right)$. Shouse et al (1982) found a good relation $\left(R^{2}=0.66\right)$ between cowpea seed yield and PWP integrated during the reproductive period.

\section{CONCLUSIONS}

Water deficits imposed on soybeans during reproductive stages $\left(R_{1}-R_{4}\right)$. $R_{4}-R_{6.3}$ significantly reduced both water use and above ground dry matter accumulation, in spite of the depth of water extraction being strongly increased by dry treatments. Seed yield was only affected by deficiencies during the grain filling period $\left(R_{4}-R_{6.3}\right)$.

The performance of soil (percentage of available water: PAW), and plant indicators (leaf water potential at predawn: PWP; noon leaf water potential; leaf resistance and leaf temperature: $L T$, showed that all excepting $L T$ had a clear response to water deficiency.

$P A W$ was used as a reference against which the other indicators were compared. PWP was the plant indicator which showed the best relationship $\left(R^{2}=0.77^{\star \star}\right)$. The ratio of actual evapotranspiration over maximum evapotranspiration was drastically reduced when PAW fell below a threshold of $62 \%(P W P=-0.14 \mathrm{Mpa})$.

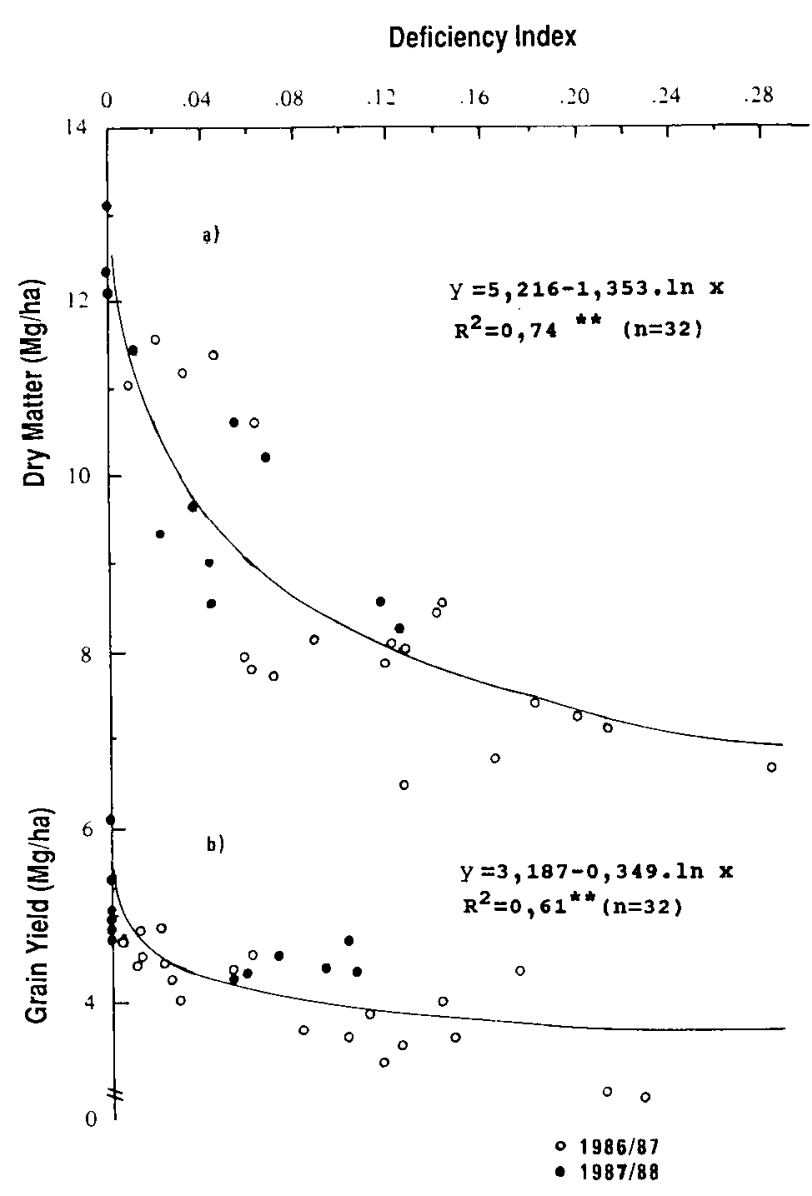

Fig 5. Soybean crop during 1986/1987 and 1987/1988. Relationship dry matter : water use. Bars represent standard deviation, when its magnitude exceeds symbol size used. 
A deficiency index wich integrated reproductive periods during which the $P A W$ was below the previously determined threshold showed significant relationships with both above-ground dry matter production $\left(R^{2}=0.74^{\star \star}\right)$ and grain yield $\left(R^{2}=0.61^{\star *}\right)$.

As an overall conclusion, PWP and PAW are considered to be reliable water deficiency indicators, and may be used to quantify the water deficit and its effect on biomass and grain production.

\section{REFERENCES}

Andriani J, Andrade F, Suero EE, Dardanelli JL (1991) Water deficit during reproductive growth of soybeans. I. Their effects on dry matter accumulation, seed yield and its components. Agronomie 11,

Ashley DA, Ethridge WJ (1978) Irrigation effects on vegetative and reproductive development of three soybean cultivars. Agron J 77, 274-278

Begg J, Turner NC (1976) Crop water deficits. Adv Agron $28,161-217$

Boyer JS (1970) Leaf enlargement and metabolic rates in corn, soybean and sunflower at various leaf water potential. Plant Physiol 46, 233-235

Brady RA, Powers WL, Stone LR, Goltz SM (1974) Relation of soybean leaf water potential to soil water potential. Agron J 66, 795-798

Brown EA, Caviness CE, Brown DA (1985) Response of selected soybean cultivars to soil moisture deficit. Agron J 77, 274-278

Brun LJ, Prunty L, Larsen JK, Enz JW (1985) Evapotranspiration and soil water relationships for spring wheat and soybean. Soil Sci 139 (6), 547-552

Burch CJ, Smith RCG, Mason WK (1978) Agronomic and physiological responses of soybean and sorghum crops to water deficits. II. Crop evaporation, soil water depletion and root distribution. Aust $J$ Plant Physiol 5, 169-177

Cate RB Jr, Nelson LA (1965) A rapid method for correlation of soil test analysis with plant response data. N Carolina Agric Exp Stn Int Soil Testing Ser Tech Bull No 1

Cate RB Jr, Nelson LA (1971) A simple statistical procedure for partitioning soil test correlation data into two classes. Soil Sci Soc Am Proc 35, 658-659

Constable $\mathrm{GH}$, Hearn $A B$ (1980) Irrigation for crops in a sub-humid environment. I. The effect of irrigation on the growth and yield of soybeans. Irrig Sci 2, 1 12

Cortes PM, Sinclair TR (1986) Water relations on fieled-grown soybean under drougth. Crop Sci 26, 993-998

Cox WJ, Jolliff GD (1986) Growth and yield of sunflower and soybean under soil water deficits. Agron $J$ $75,226-230$
Cox WJ, Jolliff GD (1987) Crop water relations of sunflower and soybean under irrigated and dry land conditions. Crop Sci 27, 553-557

Donald CM, Hanblin J (1976) The biological yield and harvest index of cereal as agronomic and plant breeding criteria. Adv Agron 28, 361-405

Doorenbos J, Pruitt WO (1977) Las Necesidades de Agua de los Cultivos. Publicación FAO, Riego y Drenaje No 24, Rome, 194 pp

Doss BD, Pearson RW, Rogers HT (1974) Effect of soil water stress at various growth stages on soybean yield. Agron J 66, 297-299

Fehr WR, Caviness CE (1977) Stages of soybean development. lowa Agric Exp Stn SR-80, 11 pp

Hanks RJ (1983) Yield and water-use relationships: an overwiew. In: Limitations to Efficient Water Use in Crop Production (Taylor HM, Jordan WR, Sinclair TR, eds) ASA-CSSA-SSSA, Madison, WI, 393-411

Heatherly LG, Russell WJ, Hincley TM (1977) Water relations and growth of soybeans in drying soil. Crop Sci 17, 381-386

Hiler EA, Howell TA, Branson Lewis R, Boos RP (1973) Irrigation Timing by the Stress Day Index Method. ASAE No 73-236

Hiler EA, Howell TA (1983) Irrigation options to avoid critical stress: an overview. In: Limitations to Efficient Water Use in Crop Production (Taylor HM, Jordan WR, Sinclair TR, eds) ASA-CSSA-SSSA, Madison, WI, 479-497

Hoogenboom G, Huck MG, Peterson CM (1987) Root growth rate of soybean as affected by drought stress. Agron J 79, 607-614

Huang C, Boyer JS, Vanderhoef LN (1975) Acetylene reduction (nitrogen fixation) and metabolic activities of soybean having various leaves and nodule water potentials. Plant Physiol 56, 222-227

Kadhem FA, Specht JE, Williams JH (1985) Soybean irrigation serially timed during stages R1 to R6. I. Agronomic responses. Agron J77, 291-298

Kanemasu ET (1983) Yield and water-use relationships: an overview. In: Limitations to efficient Water Use in Crop Production (Taylor HM, Jordan WR, Sinclair TE, eds). ASA-CSSA-SSSA, Madison, WI, 413-417

Kaspar TC, Stanley CD, Taylor HM (1978) Soybean root growth during the reproductive stages of development. Agron J 70, 1105-1107

Kaspar TC, Taylor HM, Shibles RM (1984) Taprootelongation rates of soybean cultivars in the glasshouse and their relation to field rooting depth. Crop Sci $24,916-920$

Korte LL, Williams JH, Specht JE, Sorensen RC (1983) Irrigation of soybean genotypes during reproductive ontogeny. I. Agronomic responses. Crop Sci 23, 521-527 
Kramer PJ (1983) Water Relations of Plants. Academic Press Inc, London, $489 \mathrm{pp}$

Maertens C (1986) Soja : système racinaire et exploitation du sol. In: Le Soja. Suppl inf Tech CETIOM, Paris, 33-37

Mason WK, Rowse HR, Bennie ATP, Kaspar TC, Taylor HM (1982) Response of soybeans to two row spacings and two soil water levels. II. Water use, root growth and plant water status. Field Crops Res $5,15-29$

Mayaki MV, Teare ID, Stone LR (1976) Top and root growth of irrigated and nonirrigated soybeans. Crop Sci 16, 92-95

Merrien A (1987) Cahier Technique Soja. Irrigation. CETIOM, Paris, $28 \mathrm{p}$

Mingeau M (1974) Étude de la Sensibilité du Soja à la Sécheresse. Inf Tech CETIOM 47, 1-14

Neyshabouri MR, Hatifield JL (1986) Soil water deficit effects on semi-determinate and indeterminate soybean growth and yield. Field Crops Res 15, 73-84

Puech J, Hernandez M, Salvy J (1978) Rythmes de consommation d'eau, conduite de lirrigation. In: $L e$ Soja. Station d'Agronomie de Toulouse, $133 p$

Puech J, Bouniols A (1986) Besoins en eau et en azote du soja : importance des phases sensibles. In: Le Soja. Suppl Inf Tech CETIOM, Paris, 24-31

Reicosky DC, Deaton DE (1979) Soybean water extraction, leaf water potential and evapotranspiration during drought. Agron J71, 45-50

Ritchie JT, Burnett E, Henderson RC (1972) Dryland evaporative flux in a subhumid climate. III. Soil water influence. Agron J64, 168-173
Scott HD, Ferguson JA, Scott LS (1987) Water use, yield, and dry matter accumulation by determinate soybean grown in a humid region. Agron $J 79,870$ 875

Shouse P, Jury WA, Stolzy LH, Dasberg S (1982) Field measurement and modelling of cowpea water use and yield under stressed and well-watered conditions. Hilgardia $50(6), 25$

Sionit N, Kramer JP (1976) Water potential and stomatal resistance of sunflower and soybean subjected to water stress during various growth stages. Plant Physiol 58, 537-540

Sionit N, Kramer JP (1977) Effect of water stress during differents stages of growth of soybean. Agron $J$ 69, 274-277

Snyder RL, Carlson RE, Shaw RH (1982) Tield of indeterminate soybeans in response to multiple periods of soil water stress during reproduction. Agron J74, 855-858

Turner NC, Begg JE, Rawson HM, English SD, Hearn $A B$ (1978) Agronomic and physiological responses of soybeans and sorghum crops to water deficits. III. Components of leaf water potential, leaf conductance, ${ }^{14} \mathrm{CO}_{2}$ photosynthesis, and adaptation to water deficits. Aust J Plant Physiol 5, 179-194

Van Keulen H, Van Laar HH (1986) The relation between water use and crop production. In: Modelling of Agricultural Production: Weather, Soils and Crops (Van Keulen H, Wolf J, eds) Pudoc, Wageningen, The Netherlands

Willat ST, Taylor HM (1978) Water uptake by soyabean roots as affected by their depth and soil water content. Agric Sci (Camb) 90, 205-213 